\title{
INTRALABORATORY OPTIMIZATION AND VALIDATION OF A METHOD FOR PATULIN DETERMINATION IN GRAPES BY THIN-LAYER CHROMATOGRAPHY
}

\author{
Renata Cabrera de Oliveira; Érika Bando; Miguel Machinski Junior* \\ Universidade Estadual de Maringá, Departamento de Análises Clínicas, Laboratório de Toxicologia, Maringá, PR, Brasil.
}

Submitted: June 05, 2006; Returned to authors for corrections: September 21, 2006 Approved: February 12, 2007

\begin{abstract}
The aim of this work was to optimize and validate, by intralaboratorial procedures, a method for the determination of patulin in grapes by thin-layer chromatography. The steps of extraction, cleanup, detection and quantification were optimized. For the validation of the method, recovery assays with standard solutions and artificially contaminated samples were carried out. The mean recovery and the variation coefficient were $65.4 \%$ and $7.58 \%$, respectively. The optimized conditions were: $50 \mathrm{~mL}$ of grape juice, three extraction stages (with $100 \mathrm{~mL}$ of ethyl acetate in the first stage and $50 \mathrm{~mL}$ in second and third stages), and $100 \mu \mathrm{L}$ of ethanol to solubilize the extract. The solvent-system used was toluene - ethyl acetate - formic acid (6:3:1), and 0.5\% MBTH in 5\% formic acid was sprayed on the plates to intensify the fluorescence. The visual detection and quantification limits were $7.44 \mathrm{ng}$ and $15.87 \mu \mathrm{g} \mathrm{kg}^{-1}$, respectively. The optimized and validated method demonstrated sufficient efficiency for adoption in the monitoring of patulin in grape.
\end{abstract}

Key words: patulin; mycotoxins; grape; thin-layer chromatography

\section{INTRODUCTION}

Patulin is a secondary metabolite produced by several species of filamentous fungi belonging to the genera Penicillium, Aspergillus, Byssochlamys, Gymnoascus and Paecilomyces, with Penicillium expansum considered to be the most important patulin producer (13). Many authors consider this mycotoxin as a promoter of mutagenesis $(16,18,19,22,28,31,33)$ carcinogenesis $(4,9,24)$ and teratogenesis $(6,16,29)$.

Patulin has been found to contaminate various fruits, such as apricots, cherries, grapes, pears, peaches and apples, and also products based on these fruits $(14,21)$. There are, however, few studies on the contamination of grapes and grape juice by patulin, as mentioned by Altmayer et al. (1), Czerwiecki (8), Frank et al. (15), Kubrak et al. (20), Meyer (23), and Woller and Majerus (35).

Many studies have been conducted to monitor and control the development of toxigenic mould and mycotoxin production in foods and feeds, as well as to develop simple and efficient methods for the determination of these metabolites, evaluating toxicant doses and maximum limits of tolerance for these substances in various products $(5,12,25)$.

Several countries have established the maximum limit of 50 $\mu \mathrm{g} \mathrm{kg}^{-1}$ for patulin in products for human consumption. However, other countries have been recommending the limits of $20 \mu \mathrm{g} \mathrm{kg}^{-1}$ and $30 \mu \mathrm{gkg}^{-1}$ for baby and infant foods, respectively $(11,27)$. In 1995, the Joint FAO/WHO Expert Committee on Food Additives (JECFA) modified the Provisory Tolerable Weekly Intake (PTWI) for patulin of $7 \mu \mathrm{g} / \mathrm{kg}$ body weight/week for a Provisory Maximum Tolerable Dairy Intake (PMTDI) of $0.4 \mu \mathrm{g} /$ $\mathrm{kg}$ of body weight/day (34).

Thin-layer chromatography (TLC) is the traditional technique for mycotoxin determination. Its low cost and simplicity are the main advantages of this analytical procedure. The significant separation of the mycotoxins from the non-desired compounds in this technique confers specificity and sensitivity to the method. The main disadvantage of it, however, is the low repeatability related to the process of applying the samples to the plates, development of the plates, which can be improved by the analyst's experience (7).

*Corresponding Author. Mailing address: Universidade Estadual de Maringá - Dep. de Análises Clínicas - Lab. de Toxicologia - Av. Colombo, 5790. Cep: 87020-900 Maringá, PR - Brasil. Tel.: (44) 3261-4489. E-mail: mmjunior@uem.br 
The objective of this study was to optimize and validate, by intralaboratorial procedures, the method described by Tanner and Zanier (32) for determining patulin in grapes, to make it an accessible and applicable technique for a large majority of laboratories and, at the same time, to make it capable of working within the limits of tolerance established by international legislation.

\section{MATERIALS AND METHODS}

\section{Reagents}

Standard patulin was purchased from Sigma Co. (St. Louis, MILLSTONE, USA), kept under freezing temperature and protected from light until the time of the preparation of the solutions. The standard working solutions were prepared and standardized according to AOAC (3). About $0.5 \mathrm{mg}$ of patulin was dissolved in $50 \mathrm{~mL}$ of chloroform, and $5 \mathrm{~mL}$ of this solution was transferred to a beaker and submitted to a water bath at $40^{\circ} \mathrm{C}$. Immediately after drying, the residue was dissolved in $5 \mathrm{~mL}$ of ethanol and the concentration of the standard working solution was determined spectrophotometrically by ultraviolet light at 275 $\mathrm{nm}$. It was then stored in an amber flask under refrigeration.

The stability of these solutions was monitored, repeating the standardization procedures throughout the period of the experiment. The concentrations of the standard working solutions were: $3.72,9.92,10.85,11.50,14.94,15.14$ and 16.95 $\mu \mathrm{g} \mathrm{mL}^{-1}$ in this period. The pro-analysis-grade reagents, sodium sulfate anhydrous, 3-methyl-2-benzothiazolinone hydrazone hidrocloride $(\mathrm{MBTH})$ and the TLC aluminum sheets $(20 \times 20 \mathrm{~cm})$ with silica gel $60 \mathrm{G}$ were purchased from Synth (Brazil), Merck (Germany), Sigma (USA) and Macherey-Nagel (Germany), respectively.

\section{Equipment}

The equipment used was: a waterbath (Quimis), an ultrasonic bath (Unique), a spectrophotometer (Shimadzu model UV1601PC), a pressure and vacuum pump (Marconi), an incubator (Fanem) and an ultraviolet cabinet.

\section{Samples}

Acquired commercial grape samples were blended and filtered in a sieve with a mesh size of 20 . The obtained juice was stored at $-20^{\circ} \mathrm{C}$. The samples were spiked with known quantities of patulin by the addition of the standard solution.

\section{Optimization of the method}

The method optimized was described by Tanner and Zanier (32), which quantifies the patulin in apple juice by thin-layer chromatography (TLC). The procedure consists of using $50 \mathrm{~mL}$ of the sample, extracted with $50 \mathrm{~mL}$ of ethyl acetate in the first and second stages, followed by the cleanup of the extract with $20 \mathrm{~mL}$ of $1.5 \%$ sodium carbonate solution. After drying, the residue was dissolved in chloroform $(100 \mu \mathrm{L})$ and applied to the TLC plates.

\section{a) Extraction step}

Recovery assays were carried out with grape samples spiked with 33.9 and $67.8 \mu \mathrm{g} \cdot \mathrm{L}^{-1}$ of patulin to which the extraction solvent, ethyl acetate. In order to optimize the extraction step, the quantity of extractor solvent and the number of extractions were evaluated.

\section{b) Cleanup step}

The efficiency of the cleanup step using sodium carbonate, the precipitation of proteins by the Carrez reagent and silica column chromatography was evaluated.

Glass columns were manually packed in the laboratory with $7.5 \mathrm{~g}$ of silica gel 60 (Merck, Germany) suspended in toluene. The elution was carried out with $100 \mathrm{~mL}$ of toluene - ethyl acetate (3:1) or benzene - ethyl acetate (3:1), and the influence of this step on the recovery process of the method was determined.

Some samples of grape juice were deproteinized with different volumes of Carrez Reagent (potassium ferrocyanide and zinc acetate - Synth, Brazil) to evaluate the recovery process of this method before extraction with ethyl acetate.

\section{c) Detection and quantification steps}

The chromatographic conditions evaluated were: the application of spiked samples in quantities ranging from 1 to 10 $\mu \mathrm{L}$; solvent-system in the following ratios: toluene - ethyl acetate - formic acid (5:4:1), toluene - ethyl acetate - formic acid (6:3:1), toluene - ethyl acetate - formic acid (4:5:1), chloroform - methanol (95:5), chloroform - acetone (9:1), chloroform - methanol - acetone $(1: 1: 1)$, toluene - ethyl acetate - chloroform - formic acid (38:28:26:10) and toluene - ethyl acetate (1:3); and the chromogenic reagent sprays: phenylhydrazine and MBTH for intensifying the fluorescence.

\section{Analytic procedure}

The established analytic procedure in the optimized method was as follows:

\section{a) Extraction and Cleanup}

Aliquots of $50 \mathrm{~mL}$ of homogenized grape juice were extracted with $100 \mathrm{~mL}$ of ethyl acetate by shaking manually for 1 minute. The aqueous and organic phases were then separated into different beakers. The extraction of the aqueous phase was repeated 2 more times with $50 \mathrm{~mL}$ of ethyl acetate. The total organic extract was transferred to a separation funnel and submitted to vigorous shaking with $40 \mathrm{~mL}$ of $1.5 \%$ sodium carbonate solution. The organic phase was then filtered with anhydrous sodium sulfate, and the filtrate was evaporated in a waterbath at $40^{\circ} \mathrm{C}$ until dry. The dried residue was then transferred to a small vial, redissolved ultrasonically in $3 \mathrm{~mL}$ of 
ethyl acetate for 3 minutes (i.e. one minute for each $\mathrm{ml}$ added), and evaporated under the same conditions again. The final dry residue was stored at $-20^{\circ} \mathrm{C}$.

\section{b) Thin- layer chromatography (TLC)}

To dissolve the residue, $100 \mu \mathrm{L}$ of ethanol was added and the mixture was shaken in a vortex for 1 minute. Aliquots of 5, 7 and $10 \mu \mathrm{L}$ of the sample extract and 1 to $10 \mu \mathrm{L}$ of the standard patulin working solution were applied on chromatographic plates. The solvent-system used was toluene - ethyl acetate formic acid (6:3:1). The plates were then dried, MBTH was applied to them, and visualization in ultraviolet $366 \mathrm{~nm}$ was carried out. The fluorescence intensity of stained samples was compared with those of the standards.

\section{Validation of the optimized method}

For the validation of the method, standard solutions and spiked samples $(2,10)$ were used, according to the analytic procedures established during the optimization of the method. Validation of the analytical method was based on the following criteria: selectivity, accuracy, precision and visual detection and quantification limits.

\section{a) Limit of visual detection}

The limit of visual detection was determined by using volumes of 1 to $10 \mu \mathrm{L}$ of the standard working solutions for verification of the lowest detectable quantity of patulin by visual analysis.

\section{b) Specificity, accuracy, precision and limit of quantification of the method}

The specificity of the method was evaluated through the use of grape juice samples spiked with the standard working solutions in two concentration levels ( 33.9 and $67.8 \mu \mathrm{g} \mathrm{L}^{-1}$ ) and blank samples, with all tests carried out in triplicate. The resolution of the patulin stain, the presence of non-desired compounds and the agreement among the retention factors (Rf) of the patulin and of the standard working solution and spiked samples were verified.

For the evaluation of precision, accuracy and the quantification limit of the method, blank and spiked samples, in four concentration levels, were analyzed, with at least two repetitions per level.

The precision of the method was evaluated through the variation coefficients of the results for each of the concentration levels. Repeatability and reproducibility were evaluated by the comparison of the results obtained in assays carried out on the same day, and on different days, of extraction, respectively.

Accuracy was evaluated by the comparison of the theoretical values of the patulin additions and the values obtained in the tests, expressed in terms of recovery percentage. The criteria of acceptability determined by Horwitz et al. (17) (60 to $100 \%$ accuracy and $30 \%$ precision) were used as a reference for the evaluation of the variation coefficients and mean percentages of recovery obtained in the tests.

The quantification limit of the method was determined as being the smallest patulin concentration that could be detected throughout all the assay repetitions, by considering the values of the mean recovery percentages and the variation coefficients defined as being acceptable, (60 to 100\% accuracy and 30\% precision).

\section{RESULTS AND DISCUSSION}

\section{Optimization of the method}

\section{a) Extraction step}

The use of ethyl acetate, according to the original method, i.e. $50 \mathrm{~mL}$ in the first and second extraction, did not present good recovery due to emulsification of the sample. Recoveries between 30 and $38 \%$ were obtained. The amount of solvent extractor and the number of extractions were increased to 100 $\mathrm{mL}$ of ethyl acetate in the first extraction and $50 \mathrm{~mL}$ in the second and third, according to Smith and Stewart (30). The mean recovery obtained was around $66.9 \%$. This modification contributed to the obtainment of appropriate results, according to the criteria of Horwitz et al. (17).

\section{b) Cleanup step}

The cleanup step in a silica column presented recoveries between $30 \%$ and $40 \%$, with either the toluene - ethyl acetate (3:1) or benzene - ethyl acetate (3:1) solvent-systems. These results were not acceptable.

The use of Carrez reagent, proposed by Pogosyan and Gelfand (26), was also not satisfactory, presenting recovery values between $40 \%$ and $50 \%$.

In the original method, Tanner and Zanier (32) proposed a cleanup stage using $20 \mathrm{~mL}$ of 1,5\% sodium carbonate solution to $100 \mathrm{~mL}$ of ethyl acetate. In the present optimized method, 40 $\mathrm{mL}$ of $1,5 \%$ sodium carbonate solution was used because the amount of ethyl acetate used had increased to $200 \mathrm{~mL}$. Therefore, in effect, no modification of the original method was made to this stage of the process.

\section{c) Detection step}

In the TLC, detection efficiency was observed in the elution of patulin when using toluene - ethyl acetate - formic acid (6:3:1) as the solvent-system. It presented good resolution and reproducibility of the chromatogram. The use of a non-saturated chromatographic cube enabled fast development - approximately 30 minutes.

The chromogenic agent chosen was MBTH as it presented better sensitivity, as can be seen in Table 1. The advantage of using of MBTH is that, under white light, light yellow round and compact stains are detected, and under UV light, the patulin emits orange fluorescence. 


\section{Validation of the optimized method}

The detection limit for the standard patulin solution was $7.44 \mathrm{ng}$, a mass corresponding to the smallest amount of standard working solution tested, detected visually under UV light (Table 1). The method also showed sufficient specificity in the tests using spiked samples. Non-desired compounds present in the samples could be detected as not being patulin.

The mean recoveries and variation coefficients obtained in the assays with spiked samples using the optimized method are illustrated in Table 2 . The method presented recoveries between $60 \%$ and $85 \%$, with an average of $65.4 \%$.

The variation coefficients for repeatability and reproducibility obtained for the concentrations studied ranged from 7.58 to $13.51 \%$ and 0.36 to $18.76 \%$, respectively. The mean recoveries and variation coefficients were within the established limits of acceptability according to Horwitz et al. (17), thereby demonstrating accuracy and precision.

The quantification limit was $15.87 \mu \mathrm{g} \cdot \mathrm{kg}^{-1}$, since the mean recovery and variation coefficient were $62.5 \%$ and $7.58 \%$, respectively.

\section{CONCLUSIONS}

The optimized method showed the best performance when carrying out three extractions with ethyl acetate, cleanup with $40 \mathrm{~mL}$ of sodium carbonate, the use of toluene - ethyl acetate formic acid (6:3:1) as a solvent-system and the use of $0.5 \%$
MBTH in 5\% formic acid as a chromogenic agent. Specificity was demonstrated by the separation of patulin from the nondesired matrix compounds, by the resolution of the stains and by the satisfactory recovery percentage. Accuracy and precision were observed to be in the range from 15.87 to 67.80 $\mu \mathrm{g} \mathrm{kg}$. The visual detection and quantification limits of $7.44 \mathrm{ng}$ and $15.87 \mu \mathrm{g} \mathrm{kg}^{-1}$ were within the maximum limits permitted by international legislation. The validated method demonstrated efficiency for use in the monitoring of patulin in grape products.

\section{RESUMO}

\section{Otimização e validação intralaboratorial de método para a determinação de Patulina em uva por Cromatografia em Camada Delgada}

O objetivo deste trabalho foi otimizar e validar, por procedimentos intralaboratoriais, um método de determinação de patulina em uva por cromatografia em camada delgada. Foram realizados testes de otimização das etapas de extração, limpeza, detecção e quantificação. Para validação do método foram realizados ensaios de recuperação com soluções padrões e amostras artificialmente contaminadas. A recuperação e o coeficiente de variação foram $65,4 \%$ e 7,58\%, respectivamente. As condições otimizadas foram: $50 \mathrm{~mL}$ do suco da uva; três etapas de extração, $100 \mathrm{~mL}$ de acetato de etila na primeira etapa e $50 \mathrm{~mL}$ na segunda e terceira etapas; $100 \mu \mathrm{L}$ de etanol para

Table 1. Detection limit for patulin using MBTH and phenylhydrazine, under visible and ultraviolet (366 nm) ligh..

\begin{tabular}{lcccccccc}
\hline & \multicolumn{10}{c}{ PATULIN $\left(\mathbf{3 . 7 2} \mathbf{n g} \boldsymbol{\mu \mathbf { L } ^ { - 1 }}\right)$} \\
\cline { 2 - 9 } Chromogenic agents & $(\mu \mathrm{L})$ & 1 & 2 & 3 & 4 & 5 & 6 & 7 \\
& $(\mathrm{ng})$ & 3.72 & 7.44 & 11.16 & 14.88 & 18.6 & 22.32 & 26.04 \\
\hline Phenylhydrazine & VIS & - & - & - & + & + & ++ & ++ \\
MBTH & VIS & - & - & - & + & ++ & ++ & ++ \\
MBTH & UV & $+/-$ & + & + & ++ & ++ & ++ & ++ \\
\hline
\end{tabular}

(+) visible; (+ / -) weakly visible; (UV) ultraviolet; (VIS) visible light.

Table 2. Recoveries and variation coefficients of patulin concentration in spiked grape samples.

\begin{tabular}{ccccc}
\hline $\begin{array}{c}\text { Added concentration } \\
\left(\mathrm{mg}_{\mathrm{kg}}\right)^{-1}\end{array}$ & $\begin{array}{c}\text { Mean concentration } \\
\text { found }\left(\mathrm{mg} \cdot \mathrm{kg}^{-1}\right)\end{array}$ & $\begin{array}{c}\text { MeanRecovery } \\
(\%)\end{array}$ & $\begin{array}{c}\text { Variation coefficient } \\
\text { - repeatability }(\%)\end{array}$ & $\begin{array}{c}\text { Variation coefficient } \\
- \text { reproducibility }(\%)\end{array}$ \\
\hline 15.87 & 9.92 & 62.5 & 7.58 & - \\
22.99 & 15.00 & 65.3 & 13.51 & - \\
33.90 & 24.90 & 73.4 & - & 0.36 \\
67.80 & 40.87 & 60.3 & - & 0.76 \\
\hline Mean & $\mathbf{6 5 . 4}$ & & \\
\hline
\end{tabular}


solubilizar o extrato; a fase móvel tolueno-acetato de etila-ácido fórmico (6:3:1) e o revelador o MBTH 0,5\% em ácido fórmico 5\%. O limite de detecção visual foi de 7,44 ng e o de quantificação de $15,87 \mu \mathrm{g} / \mathrm{kg}$. O método otimizado e validado apresentou eficiência para ser adotado em atividades de monitoramento de patulina em uva.

Palavras-chave: patulina; micotoxinas; uva; cromatografia em camada delgada.

\section{REFERENCES}

1. Altmayer, B.; Eichorn, K.W.; Plapp, R. (1982). Analysis of patulin in grape juices and wine. Z. Lebensm. Unters., 175(3), 175-178.

2. ANVISA - Agência Nacional de Vigilância Sanitária (2004). Guia para qualidade em Química Analítica: uma assistência a acreditação. ANVISA, Brasília.

3. AOAC INTERNATIONAL (1998). Official methods of analysis of AOAC International. 16. ed. $4^{\text {th }}$ ver. (Software Adobe and E-DOC/ CJS).

4. Becci, P.J.; Hess, F.G.; Johnson, W.D.; Gallo, M.A.; Babish, J.G.; Dailey, R.E.; Parent, R.A. (1981). Long-term carcinogenicity and toxicity studies of Patulin in the rat. J. Appl. Toxicol., 1, 256-261.

5. Bento, H.; Fernandes, A.M.; Barbosa, M. (1989). Pesquisa de aflatoxina M1 em leite corrente pasteurizado e em leite em pó. Rev. Port. Ci. Vet., 84, 163-171.

6. Ciegler, A.; Beckwith, A.C.; Jackson, L.K. (1976). Teratogenicity of patulin and patulin adducts formed with cysteine. Appl. Environ. Microbiol., 31, 664-667.

7. Coker, R.D. (1984). High performance liquid chromatography and other chemical quantification methods used in the analysis of mycotoxins in foods. In: Gilbert, J. (ed.) Analysis of food contaminants. Elsevier, London, UK, p.207-263.

8. Czerwiecki, L. (1984). Detection and determination of patulin in Polish fruit wines. Rocz. Panstw. Zakl. Hig., 35(4), 347-349.

9. Dickens, F.; Jones, H.E.H. (1961) Carcinogenic activity of a series of reactive lactones and related substances. Br.J. Cancer, 15, 85-100.

10. EURACHEM (1998). The fitness for purpose of analytical methods. A laboratory guide to method validation and related topics. Eurachem, Teddington.

11. FAO - Food and Agriculture Organization of the United Nations (1997). Worldwide regulations for mycotoxins 1995. In: FAO Food and Agriculture Organization Food and Nutrition paper 64, FAO, Rome, p.7-28.

12. FAO/WHO (2001). Evaluation of certain mycotoxins in food: fifty-sixth report of the Joint FAO/WHO. Expert Committee on Food Additives. WHO-Technical-Report-Series, n. 906, v.3. FAO, Rome.

13. Firsvad, J.C.; Thrane, U. (1996). Mycotoxin production by foodborne fungi. In: Samson, R.A.; Hoekstra, E.S.; Frisvad, J.C.; Filtenborg, O. (eds.). Introduction to Food-Borne Fungi. Centraalbureau voor Schimmelcultures Baarn, The Netherlands, p.251-260.

14. Frank, H.K.; Orth, R.; Figge, A. (1977). Patulin in foods of vegetable origin. 2. Several kinds of fruit and vegetables and fruit and vegetable products. Z. Lebensm. Unters. Forsch., 163(2), 111-114.
15. Frank, H.K.; Orth, R.; Hermann, R. (1976). Patulin in foods of vegetable origin I. Pomaceous fruit and products made out of it. $Z$. Lebensm. Unters. Forsch., 162(2), 149-157.

16. Hopkins, A.W. (1943). Patulin in the common cold. IV. Biological properties: Extended trial in the common cold. Lancet, 631-635.

17. Horwitz, W.; Albert, R.; Nesheim, S. (1993). Reliability of mycotoxin assays - an update. J. AOAC Int., 76, 461-491.

18. Kirsch, P.F. (1990). Production of a genomic DNA library in lambda phage for Penicillium patulum, and isolation and partial characterization of Patulin pathway induction-phase-specific clones from the library. Diss. Abstr. Int., 50(8), 3452b.

19. Korte, A.; Rucket, G. (1980). Chromosomal analysis in bone-marrow cells of Chinese hamsters after treatament with mycotoxins. Mutat. Res., 78, 41-50.

20. Kubrak, E.M.; Novikova, N.V.; Zhanybayeva, D.O.; Vargina, S.G. (1995). Contamination of food products by mycotoxins in Kyrgyzstan. Eurotox 95. Toxicol. Letters, 178(51), 1-81.

21. Machinski Jr., M.; Mídio, A.F. (1996). Incidencia de Patulina en jugo de manzana industrializado. Alimentaria, 276, 61-64.

22. Mayer, V.W.; Legator, M.S. (1969). Production of petite mutants of Saccharomyces cerevisae by Patulin. J. Agric. Food Chem., 17, 454-456.

23. Meyer, R.A. (1978). Occurrence of mycotoxin patulin in fruit and fruit products. Lebensm. Ind., 25(5), 224-225.

24. Osswald, H.; Frank, H.K.; Komitowksi, D.; Winter, H. (1978). Longterm testing of patulin administered orally to Sprague-Dawley rats and Swiss mice. Food Cosmet. Toxicol., 16, 243-248.

25. Pereira, M.L.; Toledo, M.C.F. (1995). Micotoxinas: impacto na saúde humana e animal e sua detecção pelo método de ELISA. Cad. Téc. Esc. Vet. UFMG, 13, 5-27.

26. Pogosyan, A.I.; Gelfand, S.Y. (1990). Determination patulin in food products. Otkrytia Izobert., 30, 219.

27. SA GOVT. GAZETTE (1990). South African Goverment Gazette. Regulations governing tolerances for fungus-produced toxins in foodstuffs. South African Goverment Gazette R313.

28. Sentein, P. (1955). Alteration du fuscau mitotique et fragmentation des chromosomes par l'action de la patuline sur l'ooueufi d'Urodeles en segmentation. C. R. Seances Soc. Biol. Fil., 149(15-18), 16211622 .

29. Smith, E.E.; Duffus, E.A.; Small, M.H. (1993). Effects of Patulin on postimplantation rat embryos. Arch. Environ. Contam. Toxicol., 25, 267-270.

30. Smith, R.V.; Stewart, J.T. (1981). Textbook of Biopharmaceutic Analysis. Lea \& Febiger, Philadelphia.

31. Stark, A.A. (1980). Mutagenicity and carcinogenicity of mycotoxins. Ann. Rev. Microbiol., 34, 335-362.

32. Tanner, H.; Zanier, C. (1976). Ueber eine neue patulin inbestimmung fruchtsaften und konzentraten. Schweiz. Z. Obst. Weinbau, 112, 656-662.

33. Vollmar, H. (1947). Versuche uber die beeinflussung des wachstums von gewebe in der guwebekultur durch Patulin. Z. Hyg. Infektionskr, $127,316$.

34. WHO - World Health Organization (1995). Evaluation of certain food additives and contaminants. In: WHO $44^{\text {th }}$ Report of the Joint Food and Agriculture Organization/World Health Organization Expert Committee on Food Additives, Technical Report Series 859. WHO, Geneva, p.36-38.

35. Woller, R.; Majerus, P. (1986). Patulin in grapes and grape nuts occurrence and conditions of formation. Wein-Wiss., 41(3), 205-210. 